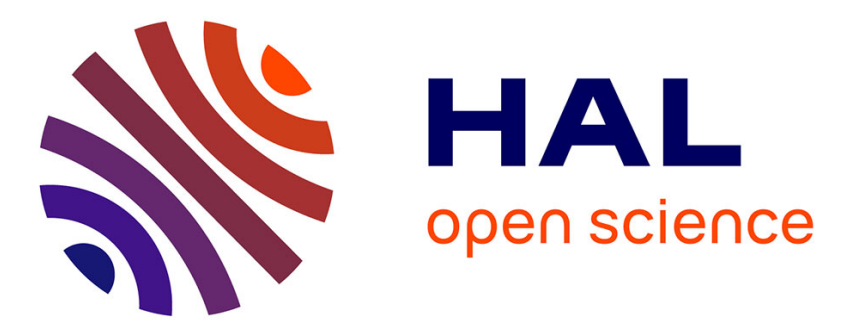

\title{
Presence of occult HBV, but near absence of active HBV and HCV infections in people infected with HIV in rural South Africa
}

Roos Emilie Barth, Quirine Huijgen, Hugo A Tempelman, Tania Mudrikova, Annemarie Mj Wensing, Andy I.M. Hoepelman

\section{To cite this version:}

Roos Emilie Barth, Quirine Huijgen, Hugo A Tempelman, Tania Mudrikova, Annemarie Mj Wensing, et al.. Presence of occult HBV, but near absence of active HBV and HCV infections in people infected with HIV in rural South Africa. Journal of Medical Virology, 2011, 83 (6), pp.929. 10.1002/jmv.22026 . hal-00633212

\section{HAL Id: hal-00633212 https://hal.science/hal-00633212}

Submitted on 18 Oct 2011

HAL is a multi-disciplinary open access archive for the deposit and dissemination of scientific research documents, whether they are published or not. The documents may come from teaching and research institutions in France or abroad, or from public or private research centers.
L'archive ouverte pluridisciplinaire HAL, est destinée au dépôt et à la diffusion de documents scientifiques de niveau recherche, publiés ou non, émanant des établissements d'enseignement et de recherche français ou étrangers, des laboratoires publics ou privés. 


\section{Presence of occult HBV, but near absence of active HBV and HCV infections in people infected with HIV in rural South Africa}

\begin{tabular}{|c|c|}
\hline Journal: & Journal of Medical Virology \\
\hline Manuscript ID: & JMV-10-2037.R1 \\
\hline Wiley - Manuscript type: & Research Article \\
\hline $\begin{array}{r}\text { Date Submitted by the } \\
\text { Author: }\end{array}$ & $11-N o v-2010$ \\
\hline Complete List of Authors: & $\begin{array}{l}\text { Barth, Roos; University Medical Centre Utrecht, Internal Medicine } \\
\text { and Infectious Diseases } \\
\text { Huijgen, Quirine; University Medical Centre Utrecht, Faculty of } \\
\text { Medicine } \\
\text { Tempelman, Hugo; Ndlovu Medical Centre } \\
\text { Mudrikova, Tania; University Medical Centre Utrecht, Internal } \\
\text { Medicine and Infectious Diseases } \\
\text { Wensing, Annemarie; University Medical Centre Utrecht, Virology } \\
\text { and Microbiology } \\
\text { Hoepelman, Andy; University Medical Centre Utrecht, Internal } \\
\text { Medicine and Infectious Diseases }\end{array}$ \\
\hline Keywords: & $\begin{array}{l}\text { hepatitis B, hepatis C, occult infection, Sub-Saharan Africa, Human } \\
\text { immunodeficiency syndrome }\end{array}$ \\
\hline
\end{tabular}

\section{SCHOLARONE Manuscripts}


JMV-10-2037

2 Presence of occult HBV, but near absence of active HBV and HCV

3 infections in people infected with HIV in rural South Africa

4

5 Running head: Occult hepatitis in rural South Africa

6

7 Roos E Barth ${ }^{* 1}$, Quirine Huijgen ${ }^{2}$, Hugo A Tempelman ${ }^{3}$, Tania Mudrikova ${ }^{1}$, Annemarie MJ

8 Wensing $^{4}$, Andy IM Hoepelman ${ }^{1}$

9

10 1: University Medical Centre Utrecht, Department of Internal Medicine and 11 Infectious Diseases. Utrecht, the Netherlands

$12{ }^{2}$ : Medical student at the University Medical Centre Utrecht. Utrecht, the $13 \quad$ Netherlands

14 3: Ndlovu Medical Centre, Elandsdoorn, Limpopo, South Africa

15 4: University Medical Centre Utrecht, Department of Virology and Microbiology.

16 Utrecht, the Netherlands

18 This work was performed both at the Ndlovu Medical Centre in South Africa and at the

19 University Medical Centre Utrecht in the Netherlands

20

21 Correspondence to*:

22 Roos E Barth 
1 University Medical Centre Utrecht

$2 \quad F 02.126$

3 Postbus 85500

43508 GA Utrecht

5 The Netherlands

6 E-mail: $\underline{\text { r.e.barth@University Medical Centre Utrechttrecht.nl }}$

7 Tel no: 0031-621224407

8 Fax no: 0031-302523741

9 


\section{Abstract:}

2 Human immunodeficiency (HIV), hepatitis B (HBV) and hepatitis C (HCV) viruses are

3 endemic in Sub-Saharan Africa, but data regarding the prevalence of hepatitis co-

4 infections in HIV-positive individuals residing there are limited. The aim of the study was

5 to determine the prevalence of HBV, HCV and occult HBV (presence of HBV-DNA in the

6 absence of $\mathrm{HBsAg}$ ) in a rural, South African cohort. The results were compared to

7 various ethnic groups in a Dutch cohort of people infected with HIV. Antiretroviral-naïve

8 individuals with HIV from both a rural South African clinic $(n=258)$, and a Dutch

9 University hospital $(n=782)$, were included. Both serological (HBV and HCV) and

10 molecular (occult HBV) assays were performed. Logistic regression analysis was used to

11 define independent predictors of a hepatitis co-infection.

$12 \mathrm{HBV}$ and HCV prevalence rates in the South African cohort were exceptionally low $(0.4 \%$,

$131 / 242$ and $0.8 \%, 2 / 242$ respectively), compared to those observed in Caucasians (HBV

14 4.4\%, HCV 10.9\%) and African immigrants (HBV 8.9\%, HCV 4.8\%). Conversely, occult HBV

15 was observed in a considerable proportion $(10 \%, 6 / 60)$ of South African patients who

16 were anti-HBc-positive but $\mathrm{HBsAg}$-negative. Occult infections were less frequent in

17 Caucasians and Africans in the Dutch cohort (3.2\% and 1.4\% respectively). Independent

18 predictors for occult HBV were not identified, but a trend towards more occult HBV at

19 lower CD4 counts was observed.

20 Local HBV/HCV prevalence data are needed to optimise vaccination and antiretroviral

21 treatment strategies. Occult HBV in patients with HIV may be missed regularly when

22 molecular analyses are not available. 


\section{Keywords:}

2 Hepatitis B

3 Hepatitis C

4 Human immunodeficiency virus

5 Occult infection

6 HBV-DNA

7 Sub-Saharan Africa 


\section{Introduction:}

2 Millions of people are infected with human immunodeficiency virus (HIV), hepatitis B

3 virus (HBV) and hepatitis C virus (HCV) globally. Sub-Saharan Africa is affected severely

4 by all three viruses; two-third of the world's 33 million people infected with HIV reside

5 there, as well as an estimated 50 million chronic HBV carriers [Modi and Feld, 2007;

6 WHO, 2002; WHO, 2007]. In addition, three percent of the African population is thought

7 to be infected with HCV [Madhava et al., 2002].

8 Chronic hepatitis can lead to cirrhosis and hepatocellular carcinoma. Due to shared

9 routes of transmission, the prevalence of HBV and HCV is believed to be high amongst

10 persons infected with HIV [Burnett et al., 2005; Thomson and Main, 2008]. Life

11 expectancy of people living with HIV in Sub-Saharan Africa has improved dramatically

12 since the increased availability of antiretroviral treatment (ART). The long-term effects

13 of HBV and HCV co-infections will therefore become more evident, causing a potential

14 increase in morbidity and mortality [Hoffmann and Thio, 2007; Modi and Feld, 2007].

15 This is stressed by the observation that the progression of HBV-and HCV-related liver

16 disease is more rapid in patients with HIV [Chen et al., 2009; Nikolopoulos et al., 2009].

17 Prior to starting ART, it is important to know whether a co-infection with hepatitis is

18 present. An increased hepatotoxicity of antiretrovirals (ARVs) and other drugs is

19 observed in patients with both HIV and hepatitis, compared to those with HIV infection

20 alone [den Brinker et al., 2000; Hoffmann et al., 2007; Sulkowski et al., 2002]. Although

21 immune reconstitution soon after initiating ART may cause further liver damage, ART 
1 may be beneficial for patients who are co-infected with HIV and HBV, as it can be used

2 to treat both infections simultaneously.

3

4 Screening for co-infection with HBV or HCV in people infected with HIV is incorporated 5 in western clinical guidelines [BHIVA, 2010; EACS, 2009; Soriano et al., 2008; Soriano et

6 al., 2007]. However, consequent serological screening for hepatitis is generally not

7 feasible in low-income countries (LICS). As a result, limited HBV and HCV prevalence

8 data are available regarding African patients infected with HIV, and the data that are

9 available indicate wide geographical variation [Cooper et al., 2009; Hoffmann and Thio,

10 2007; Marcellin, 2009].

11 While some people have an active, HBV surface antigen (HBsAg) positive infection,

12 others may harbour an occult HBV infection. Occult hepatitis B is defined by the

13 presence of plasma HBV-DNA in individuals who are HBsAg negative. Even if serological

14 testing for HBV is available, such infections will be missed.

16 The aim of the current study is to assess active HBV, occult HBV and HCV prevalence

17 rates in a cohort of people infected with HIV in rural South Africa. The results were

18 compared to co-infection rates with HBV and HCV among Caucasian and African

19 individuals with HIV in the Netherlands. Furthermore, predictors for the presence of

20 these hepatitis viruses were determined. 
1 Methods:

\section{Setting and study population}

3 Ndlovu Medical Centre is a non-governmental organisation in Elandsdoorn

4 (www.ndlovucaregroup.com). Elandsdoorn is situated in a rural area in Limpopo, a

5 province in the north east of the Republic of South Africa. The centre provides primary

6 health care, including an ART program for people with HIV that has been active since

7 2003. Cohort details have been described elsewhere [Barth et al., 2008]. For this study,

8 all ART-naïve adults ( $\geq 15$ years) with HIV who enrolled in the Ndlovu ART program from

9 September till November 2008, were included in this study.

10 The University Medical Centre Utrecht is an academic hospital in the city of Utrecht,

11 situated in the centre of the Netherlands. All adults ( $\geq 18$ years) with HIV, who came into

12 care at the University Medical Centre Utrecht from January 1985 till January 2008, were

13 included. Patients were ART-naïve at time of serological HBV and HCV testing.

14 For comparisons, analyses were limited to African and Caucasian people. Asians and 15 people originating from the Americas who were in care at the University Medical Centre 16 Utrecht were excluded.

\section{Data collection and definitions}

19 Patient characteristics were extracted from medical charts and clinical databases. Data

20 included in the study were the following: age, gender, ethnicity, country of birth,

21 probable route of HIV transmission and baseline laboratory variables (CD4+ T-cell count, 22 ASAT, ALAT). Venous blood was collected from all patients, and standard methods for 
1 blood sample processing were used. Plasma was locally stored at $-80^{\circ} \mathrm{C}$ and shipped to

2 the Netherlands on dry ice.

3 HBV and HCV analyses were performed at the accredited (according to Dutch guidelines)

4 diagnostic laboratory of the virology department at the University Medical Centre

5 Utrecht. Serological tests for HBV (anti-HBc, HBsAg and anti-HBs) and HCV (anti-HCV)

6 were performed using the AxSYM ${ }^{\circledast}$ automated analyzer (Abbott Laboratories, Abbott

7 Park, IL, USA). Anti-HBc was determined using the $\operatorname{CORE}^{\mathrm{tm}^{\circledast}}$ kit (Abbott Laboratories,

8 Abbott Park, IL, USA). Anti-HBc was considered positive if the ratio was above 1. All anti-

9 HBc-positive blood samples were tested for HBsAg and anti-HBs using $\mathrm{HBsAg}(\mathrm{V} 2)$ and

10 AUSAB ${ }^{\oplus}$ kits (Abbott Laboratories, Abbott Park, IL, USA). Ratios above 4 and 2 were used

11 to define positive anti-HBs and positive HBsAg respectively. In the case of an

12 indeterminate HBsAg result (ratio between 2 and 5) samples were centrifuged using an

13 Eppendorf centrifuge and retested.

14 HBV-DNA load was assessed in samples that tested anti-HBc positive, but did not have

15 detectable HBsAg levels. Quantitative HBV-DNA was determined using the Taqman ${ }^{\varpi}$ fast

16 real-time nested PCR, as described previously [Cohen Stuart et al., 2009; Pas et al.,

17 2000]. HBV-DNA was isolated using an automated nucleic acid extraction system

18 (MagNA Pure LC ; Roche Diagnostics, Penzberg, Germany). Lower limit of quantification

19 is $200 \mathrm{IU} / \mathrm{mL}$; lower limit of detection is $10 \mathrm{IU} / \mathrm{mL}$. Amplification was performed in

20 duplicate and a three-tiered control was executed (internal, no template and whole

21 procedure control). Outcomes were averaged and in the case of a 3-point difference in 
1 cycle threshold values (Ct values) or a positive/negative difference, the procedures were

2 repeated.

3 A positive HBsAg result was used to define an HBV infection. Patients with detectable

4 HBV-DNA levels were considered to have HBV viremia. Patients with detectable HBV-

5 DNA levels with the absence of HBV surface antigens were considered to have occult

6 HBV infections.

7 The HCV version $3.0 \mathrm{kit}^{\oplus}$ (Abbott Laboratories, Abbott Park, IL, USA) was used to

8 determine the presence of anti-HCV. A ratio above 5 was considered positive. Blood

9 samples with indeterminate results (ratio between 1 and 5), were centrifuged and

10 retested. Subsequently, a western blot was performed on all blood samples with a ratio

11 above 1, using the Autoblot $3000^{\circ}$ (Innogenetics NV, Gent, Belgium). A positive western

12 blot in anti-HCV positive individuals was used to define an HCV infection.

\section{Statistical analysis:}

15 Frequencies were compared using the $\chi 2$ and Fischer's exact tests. Continuous data 16 were compared with the independent-sample t-test or Mann Whitney $U$ test for non-

17 parametric data. Determinants that were associated with the outcome in univariate

18 analysis (defined as a p-value <0.1) were included in multivariate analysis. Subsequently,

19 logistic regression analysis was done to determine independent predictors of the

20 outcome. A P-value $\leq 0,05$ was used to define statistical significance. Data were

21 processed and statistical analyses were done using SPSS version 15. 


\section{Results:}

2 Patient characteristics:

3 Two hundred forty-eight ART naïve adults with HIV from Elandsdoorn, South Africa were

4 included in this study. The majority of included patients were female (73.8\%). The Dutch

5 cohort consisted of 846 people infected with HIV. Caucasian Europeans $(614,73 \%)$ and

6 African immigrants $(168,20 \%)$ predominated. In contrast to the South African cohort,

7 more males were included in the Dutch cohort; 535 (87\%) of Caucasians and 93 (55\%) of

8 African immigrants were male. Heterosexual contact was the main route of HIV

9 transmission in African immigrants and was assumed to be the HIV-transmission route in

10 all South African residents. With Caucasian Europeans, HIV was transmitted frequently

11 via homosexual contact. Baseline characteristics are summarised in Table 1.

\section{Serological evidence of HBV and HCV co-infections:}

14 Anti-HBc test results were available for $98 \%(242 / 248)$ of South African residents. Of the

15242 patients, 68 (28.1\%) tested positive. Most anti-HBc positive patients were anti-HBs

16 positive as well (62.7\%). Only one individual tested HBV surface-antigen positive. This

17 patient did not have anti-HBs. Overall, the prevalence of active HBV was only $0.4 \%$

18 (1/242). Serological evidence of an HBV infection was predominantly present in men;

$19 \mathrm{HBsAg}$ and anti-HBc prevalence rates were $5.4 \%$ and $45.9 \%$ in men, compared to $2.3 \%$

20 and $34.1 \%$ in women ( $p=0.2$ and $p<0.01$ respectively). No gender difference was seen

21 with regard to the anti-HBs prevalence. 
1 Compared to the South African cohort, anti-HBc prevalence rates were significantly

2 higher in both Caucasians and African immigrants $(41.4 \%$ and $57.6 \%$ respectively,

$3 \mathrm{p}<0.01)$. Furthermore, a larger proportion of patients was HBsAg-positive, resulting in an

4 active HBV prevalence of $4.4 \%$ in Caucasians and $8.9 \%$ in African immigrants $p<0.01$ ).

5 The prevalence of active HBV remained significantly lower in the South African cohort,

6 as compared to the other groups, when patients infected via heterosexual contact only

7 were included.

9 Serological evidence of an HCV infection was also infrequent in the South African cohort.

10 The anti-HCV prevalence rate was $0.8 \%$ for African residents, compared to $10.9 \%$ and

$114.8 \%$ for Caucasians and African immigrants respectively $(p<0.01)$.

12 All serological outcome data are presented in Table 2.

\section{Occult HBV infections:}

15 The presence of HBV-DNA was assessed in 93\% (62/67) of South African patients who 16 were anti-HBc positive but tested HBsAg negative. For the remaining 5 individuals, an 17 insufficient amount of plasma was stored to perform molecular analyses. An occult HBV 18 infection was established in 9.7\% (6/62) of tested individuals. HBV-DNA levels were low 19 in patients with an occult HBV infection. In 3 patients, viral loads were below the level of 20 quantification (between 10 and $200 \mathrm{IU} / \mathrm{mL}$ ), twice just above this threshold (224 and $21259 \mathrm{IU} / \mathrm{mL}$ respectively), and only once clearly higher $(5222 \mathrm{IU} / \mathrm{mL})$. 
1 For 259 Dutch patients who were anti-HBc positive and HBsAg negative, HBV-DNA levels

2 were also determined. Occult HBV was present in $2.7 \%(7 / 259)$ of these patients. The

3 prevalence rate was higher in Caucasians (6/187, 3.2\%) compared to African immigrants

$4(1 / 72,1.4 \%)$, but significantly lower compared to the South African cohort $(p=0.04)$.

5 Nearly half of the patients with occult HBV also had anti-HBs $(6 / 13,46 \%)$.

6

7 Predictors for co-infections with $\mathrm{HBV}$ or HCV:

8 Age, gender, ethnic origin, HIV transmission route, baseline log HIV-RNA and baseline

9 CD4+ T-cell count were tested as possible determinants for having a HBV or HCV co-

10 infection. In univariate analysis, all but the CD4+ T cell count were associated with the

11 presence of $\mathrm{HBsAg}$ and with the presence of anti-HCV. In multivariate analysis, only

12 lower age and male gender were independently predictive of an HBV infection. The

13 determinants that remained associated with a positive anti-HCV test were Caucasian

14 ethnicity, HIV transmission route (IVDU or blood products) and a lower baseline log HIV-

15 RNA.

16 Among anti-HBc positive individuals, the above mentioned determinants and the

17 presence of anti-HCV and anti-HBs were tested as possible predictors for an occult HBV

18 infection. None remained associated significantly with this outcome in the multivariate

19 analysis, but a trend towards a higher occult HBV prevalence in case of a lower baseline

20 CD4+ T-cell count was observed (Table 3). 


\section{Discussion:}

2 In this study an exceptionally low prevalence of HBs antigenemia (0.4\%) and HCV 3 antibodies (0.8\%) was found in a rural South African cohort of people infected with HIV.

4 Occult HBV on the other hand was observed in a considerable proportion (10\%) of 5 patients who tested anti-HBc-positive and HBsAg-negative.

6

7 In Western countries, HBV is clearly more prevalent in people with HIV compared to 8 people without HIV [Burnett et al., 2005; Kellerman et al., 2003; Thio, 2009]. This 9 relationship is attributed to common routes of transmission. In Sub-Saharan Africa the

10 association between HBV and HIV infections is less apparent, as people generally come 11 into contact with HBV long before the acquisition of HIV. Without making a distinction

12 between people with and without HIV, HBsAg prevalence in Africa is reported to be well

13 over 8\% [Barth RE, 2010; Burnett et al., 2005; CDC, 2006; WHO, 2002]. A similar rate was

14 observed among African immigrants in the current study. Published HBsAg prevalence

15 data among South African patients infected with HIV vary (5-23\%, [Burnett et al., 2007;

16 Firnhaber et al., 2009; Hoffmann et al., 2008; Lukhwareni et al., 2009; Mphahlele et al.,

17 2006]), but all are well above that observed in the cohort presented here. This is

18 remarkable, as HBV prevalence rates are generally assumed to be high in rural African

19 areas [Abdool Karim et al., 1989; Kew, 1996]. It is unclear why the observed HBV

20 prevalence in this cohort is so low. Contact with high-endemic areas was possibly limited

21 due to geographical and ethnic factors that may have reduced the amount of migration

22 and number of interracial marriages. 
1 The paradigm is that the vast majority of people in Sub-Saharan Africa come into

2 contact with HBV early in life. This would result in the presence of anti-HBc in $70-95 \%$ of

3 individuals [Burnett et al., 2005; Modi and Feld, 2007]. However, the majority (73\%) of

4 patients infected with HIV in this South African cohort lacked anti-HBc. These results are

5 in line with other studies in South Africa that reported rather low anti-HBc prevalence

6 rates (35-38\%, [Burnett et al., 2007; Firnhaber et al., 2009; Lukhwareni et al., 2009]).

7 People without anti-HBC are still at risk for acquiring HBV. Therefore, providing them

8 with an HBV vaccine may be worth considering. Such vaccination is common practice in

9 western countries. Future studies will have to establish the risk of acquiring HBV at an

10 older age in African settings and determine whether routine vaccination of patients with

11 HIV who test anti-HBc negative is cost-effective there.

12 Reported anti-HCV prevalence rates for peoples infected with HIV in Africa vary; for

13 South Africa 1 to $13 \%$ of people with HIV are believed to be co-infected with HCV

14 [Lodenyo et al., 2000; Mphahlele et al., 2006; Parboosing et al., 2008]. In LICs, the

15 clinical consequences of being infected with HCV are limited. Treating HCV is generally

16 not feasible due to high costs and frequent adverse events associated with currently

17 available therapies. Moreover, a HCV vaccine is not yet available.

18 Although active HBV was detected rarely in the current study, a considerable proportion

19 of anti-HBC positive patients in South Africa harboured an occult HBV co-infection.

20 Previous South African studies reported approximately $23 \%$ of people with HIV - who

21 tested anti-HBc positive and HBsAg negative - to have detectable HBV-DNA levels

22 [Lukhwareni et al., 2009; Mphahlele et al., 2006]. In one study that included severely 
1 immunocompromised patients infected with HIV (mean CD4+ t-cell count 49 cells $/ \mathrm{mm}^{3}$ ),

2 an even higher rate of occult HBV (88\%) was found [Firnhaber et al., 2009]. These

3 observations contribute to the idea that occult HBV represents opportunistic viral

4 reactivation [Cohen Stuart et al., 2009; Lo Re et al., 2007; Shire et al., 2007]. In the

5 current study, a significant association between the level of immunosuppression and the

6 presence of occult HBV was not found, but a trend towards more occult infections in the

7 case of a lower CD4 count was observed. In accordance with other African cohorts

8 [Harania et al., 2008; Nagu et al., 2008], no correlation between the CD4+ T-cell count

9 and the presence of an active HBV or HCV infection was found. The idea that HCV-

10 infected individuals show the highest occult HBV prevalence [Raimondo et al., 2007]

11 could not be confirmed by the data presented here.

12 In patients having an occult HBV infection only, occult HBV is linked to the transmission

13 of HBV and the development of liver disease [Raimondo et al., 2007]. However, in the

14 absence of prospective studies, it is unclear whether occult infections are associated

15 with higher liver-related morbidity and mortality rates. Moreover, the clinical relevance

16 of occult HBV is debatable as HBV-DNA loads are generally low and are likely to become

17 undetectable with lamivudine, the only drug with anti-HBV activity included frequently

18 in African ART regimens [Cohen Stuart et al., 2009].

20 There are potential limitations to this study. First, molecular analyses were limited to

21 anti-HBc positive individuals. Although an occult HBV infection is associated with the

22 presence of anti-HBV antibodies, a minority of occult carriers are negative for all HBV 
1 serum markers [Torbenson and Thomas, 2002]. Such cases would not have been

2 identified. Second, due to the low HBV-DNA levels (all but one $<1000$ copies/mL) and

3 the limited amount of plasma available, in-depth virological characterisation of HBV-

4 DNA positive specimens was not performed. The possibility of a false positive result can

5 therefore not be ruled out completely, but is unlikely considering the extensive control

6 procedure that was applied. Third, the cohorts under study vary with regard to gender

7 distribution, nadir CD4 counts and routes of transmission. This may have contributed to

8 the observed difference in co-infection rates. Nonetheless, the results remain of interest

9 as the differences in baseline characteristics represent how the epidemics vary between

10 different geographical areas.

11

12 In conclusion, an exceptionally low frequency of HBV and HCV was observed in a cohort

13 of individuals infected with HIV in rural South Africa. Rates were lower compared to

14 both Caucasians and African immigrants who are receiving care in the Netherlands.

15 Occult HBV on the other hand was observed more often in the South African cohort.

16 This study highlights the need for local HBV/HCV prevalence data in order to guide

17 decisions on future vaccination and treatment strategies.

18

19 Conflicts of Interest:

20 The authors have no conflicts of interest to declare.

21 Ethics Statement: 
1 This study was performed in compliance with relevant laws and institutional guidelines

2 and in accordance with the ethical standards of the Declaration of Helsinki.

3 Due to the retrospective nature of this study, no experiments were performed; only

4 data used for clinical practice were included. 


\section{References:}

2

Abdool Karim SS, Thejpal R, Singh B. 1989. High prevalence of hepatitis B virus infection in rural black adults in Mseleni, South Africa. Am J Public Health 79(7):893-894.

Barth RE, van der Meer JT, Hoepelman Al, Schrooders PA, van de Vijver DA, Geelen SP, Tempelman HA. 2008. Effectiveness of highly active antiretroviral therapy administered by general practitioners in rural South Africa. Eur J Clin Microbiol Infect Dis 27(10):977-984.

Barth RE, Huigen Q, Taljaard J, Hoepelman AIM. 2010. Hepatitis B/C and HIV in SubSaharan Africa: an association between highly prevalent infectious diseases. A systematic review and meta-analysis. International Journal of Infectious Diseases: accepted for publication.

British HIV Association. 2010. Guidelines for the management of coinfection with HIV-1 and hepatitis $B$ or $C$ virus. Available at: http://www.bhiva.org/documents/Guidelines/HepBC/2010/hiv 2781.pdf.

Burnett RJ, Francois G, Kew MC, Leroux-Roels G, Meheus A, Hoosen AA, Mphahlele MJ. 2005. Hepatitis $B$ virus and human immunodeficiency virus co-infection in subSaharan Africa: a call for further investigation. Liver Int 25(2):201-213.

Burnett RJ, Ngobeni JM, Francois G, Hoosen AA, Leroux-Roels G, Meheus A, Mphahlele MJ. 2007. Increased exposure to hepatitis B virus infection in HIV-positive South African antenatal women. Int J STD AIDS 18(3):152-156.

CDC. 2006. Prevalence of chronic infection with hepatitis $B$ virus. Available at: http://wwwnc.cdc.gov/travel/yellowbook/2010/chapter-2012/hepatitis-b.aspx.

Chen TY, Ding EL, Seage lii GR, Kim AY. 2009. Meta-analysis: increased mortality associated with hepatitis $C$ in HIV-infected persons is unrelated to HIV disease progression. Clin Infect Dis 49(10):1605-1615.

Cohen Stuart JW, Velema M, Schuurman R, Boucher CA, Hoepelman AI. 2009. Occult hepatitis $B$ in persons infected with HIV is associated with low CD4 counts and resolves during antiretroviral therapy. J Med Virol 81(3):441-445.

Cooper CL, Mills E, Wabwire BO, Ford N, Olupot-Olupot P. 2009. Chronic viral hepatitis may diminish the gains of HIV antiretroviral therapy in sub-Saharan Africa. Int J Infect Dis 13(3):302-306.

den Brinker M, Wit FW, Wertheim-van Dillen PM, Jurriaans S, Weel J, van Leeuwen R, Pakker NG, Reiss P, Danner SA, Weverling GJ, Lange JM. 2000. Hepatitis B and C virus co-infection and the risk for hepatotoxicity of highly active antiretroviral therapy in HIV-1 infection. Aids 14(18):2895-2902.

EACS. 2009. Guidelines clinical management and treatment of chronic hepatitis B and C co-infection in HIV-infected adults. Available at: http://www.europeanaidsclinicalsociety.org/guidelinespdf/3 Chronic Hepatitis B \& C.pdf.

Firnhaber C, Viana R, Reyneke A, Schultze D, Malope B, Maskew M, Di Bisceglie A, MacPhail P, Sanne I, Kew M. 2009. Occult hepatitis B virus infection in patients 
with isolated core antibody and HIV co-infection in an urban clinic in Johannesburg, South Africa. Int J Infect Dis 13(4):488-492.

Harania RS, Karuru J, Nelson M, Stebbing J. 2008. HIV, hepatitis B and hepatitis C coinfection in Kenya. Aids 22(10):1221-1222.

Hoffmann CJ, Thio CL. 2007. Clinical implications of HIV and hepatitis B co-infection in Asia and Africa. Lancet Infect Dis 7(6):402-409.

Hoffmann CJ, Charalambous S, Thio CL, Martin DJ, Pemba L, Fielding KL, Churchyard GJ, Chaisson RE, Grant AD. 2007. Hepatotoxicity in an African antiretroviral therapy cohort: the effect of tuberculosis and hepatitis B. Aids 21(10):1301-1308.

Hoffmann CJ, Charalambous S, Martin DJ, Innes C, Churchyard GJ, Chaisson RE, Grant $A D$, Fielding $K L$, Thio $C L$. 2008. Hepatitis $B$ virus infection and response to antiretroviral therapy (ART) in a South African ART program. Clin Infect Dis 47(11):1479-1485.

Kellerman SE, Hanson DL, McNaghten AD, Fleming PL. 2003. Prevalence of chronic hepatitis $B$ and incidence of acute hepatitis $B$ infection in human immunodeficiency virus-infected subjects. J Infect Dis 188(4):571-577.

Kew MC. 1996. Progress towards the comprehensive control of hepatitis B in Africa: a view from South Africa. Gut 38 Suppl 2:S31-36.

Lo Re V, 3rd, Frank I, Gross R, Dockter J, Linnen JM, Giachetti C, Tebas P, Stern J, Synnestvedt M, Localio AR, Kostman JR, Strom BL. 2007. Prevalence, risk factors, and outcomes for occult hepatitis B virus infection among HIV-infected patients. J Acquir Immune Defic Syndr 44(3):315-320.

Lodenyo H, Schoub B, Ally R, Kairu S, Segal I. 2000. Hepatitis B and C virus infections and liver function in AIDS patients at Chris Hani Baragwanath Hospital, Johannesburg. East Afr Med J 77(1):13-15.

Lukhwareni A, Burnett RJ, Selabe SG, Mzileni MO, Mphahlele MJ. 2009. Increased detection of HBV DNA in HBsAg-positive and HBsAg-negative South African HIV/AIDS patients enrolling for highly active antiretroviral therapy at a Tertiary Hospital. J Med Virol 81(3):406-412.

Madhava V, Burgess C, Drucker E. 2002. Epidemiology of chronic hepatitis C virus infection in sub-Saharan Africa. Lancet Infect Dis 2(5):293-302.

Marcellin P. 2009. Hepatitis B and hepatitis C in 2009. Liver Int 29 Suppl 1:1-8.

Modi AA, Feld JJ. 2007. Viral hepatitis and HIV in Africa. AIDS Rev 9(1):25-39.

Mphahlele MJ, Lukhwareni A, Burnett RJ, Moropeng LM, Ngobeni JM. 2006. High risk of occult hepatitis B virus infection in HIV-positive patients from South Africa. J Clin Virol 35(1):14-20.

Nagu TJ, Bakari M, Matee M. 2008. Hepatitis A, B and C viral co-infections among HIVinfected adults presenting for care and treatment at Muhimbili National Hospital in Dar es Salaam, Tanzania. BMC Public Health 8:416.

Nikolopoulos GK, Paraskevis D, Hatzitheodorou E, Moschidis Z, Sypsa V, Zavitsanos X, Kalapothaki V, Hatzakis A. 2009. Impact of hepatitis B virus infection on the progression of AIDS and mortality in HIV-infected individuals: a cohort study and meta-analysis. Clin Infect Dis 48(12):1763-1771. 
Parboosing R, Paruk I, Lalloo UG. 2008. Hepatitis C virus seropositivity in a South African

2 Cohort of HIV co-infected, ARV naive patients is associated with renal

Pas SD, Fries E, De Man RA, Osterhaus AD, Niesters HG. 2000. Development of a quantitative real-time detection assay for hepatitis $B$ virus DNA and comparison with two commercial assays. J Clin Microbiol 38(8):2897-2901.

Raimondo G, Pollicino T, Cacciola I, Squadrito G. 2007. Occult hepatitis B virus infection. J Hepatol 46(1):160-170.

Shire NJ, Rouster SD, Stanford SD, Blackard JT, Martin CM, Fichtenbaum CJ, Sherman KE. 2007. The prevalence and significance of occult hepatitis $B$ virus in a prospective cohort of HIV-infected patients. J Acquir Immune Defic Syndr 44(3):309-314.

Soriano V, Puoti M, Sulkowski M, Cargnel A, Benhamou Y, Peters M, Mauss S, Brau N, Hatzakis A, Pol S, Rockstroh J. 2007. Care of patients coinfected with HIV and hepatitis C virus: 2007 updated recommendations from the HCV-HIV International Panel. Aids 21(9):1073-1089.

Soriano V, Puoti M, Peters M, Benhamou Y, Sulkowski M, Zoulim F, Mauss S, Rockstroh J. 2008. Care of HIV patients with chronic hepatitis B: updated recommendations from the HIV-Hepatitis B Virus International Panel. Aids 22(12):1399-1410.

Sulkowski MS, Thomas DL, Mehta SH, Chaisson RE, Moore RD. 2002. Hepatotoxicity associated with nevirapine or efavirenz-containing antiretroviral therapy: role of hepatitis C and B infections. Hepatology 35(1):182-189.

Thio CL. 2009. Hepatitis B and human immunodeficiency virus coinfection. Hepatology 49(5 Suppl):S138-145.

Thomson EC, Main J. 2008. Epidemiology of hepatitis C virus infection in HIV-infected individuals. J Viral Hepat 15(11):773-781.

Torbenson M, Thomas DL. 2002. Occult hepatitis B. Lancet Infect Dis 2(8):479-486.

WHO. 2002. Hepatitis B. Department of communicable diseases surveillance and response. Accessed at: http://www.who.int/csr/disease/hepatitis/HepatitisB whocdscsrlyo2002 2002. pdf.

WHO. 2007. Sub-Saharan Africa. AIDS epidemic update Regional Summary. Accessed at: http://data.unaids.org/pub/Report/2008/JC1526 epibriefs subsaharanafrica en .pdf. 
Table 1: Baseline characteristics of the different cohorts of persons who were infected with HIV, but antiretroviral naïve

\begin{tabular}{|c|c|c|c|c|c|}
\hline & $\begin{array}{l}\text { Caucasians }^{a} \\
\quad(n=614)\end{array}$ & $\begin{array}{c}\text { African } \\
\text { immigrants } \\
(n=168)\end{array}$ & $\begin{array}{c}\text { Asian } \\
\text { immigrants } \\
(n=34)\end{array}$ & $\begin{array}{c}\text { South American } \\
\text { immigrants }{ }^{b} \\
(n=30)\end{array}$ & $\begin{array}{l}\text { South African } \\
\text { residents } \\
(n=248)\end{array}$ \\
\hline Age, years; mean (SD) & $40,1(10,4)$ & $31,8(8,6)$ & $34,0(7,9)$ & $34,7(8,2)$ & $40,5(9,4)$ \\
\hline Female gender; $\mathrm{n}(\%)$ & 79 (13) & $93(55)$ & $12(35)$ & $8(27)$ & $158(74)$ \\
\hline HIV-transmission route; $\mathrm{n}(\%)$ & 28 & & & & \\
\hline - Heterosexual & $180(29)$ & $156(93)$ & $25(74)$ & $17(57)$ & $250(100)^{c}$ \\
\hline - Homosexual & $371(60)$ & $4(2)$ & $9(26)$ & $13(43)$ & - \\
\hline - Blood products & $20(3)$ & $2(1)$ & - & - & - \\
\hline - IV drug use & $26(4)$ & $1(1)$ & - & - & - \\
\hline - Unknown & $17(3)$ & $5(3)$ & - & - & - \\
\hline CD4, cells $/ \mathrm{mm}^{3}$; median (IQR) & 337 (159-549) & $264(155-420)$ & $232(137-503)$ & $378(115-625)$ & 273 (91-393) \\
\hline ASAT, U/I; median (IQR) & $31(24-43)$ & $35(27-50)$ & $33(24-43)$ & $36(28-49)$ & $32(20-52)^{d}$ \\
\hline ALAT, U/I; median (IQR) & $27(20-44)$ & $22(16-35)$ & $31(17-47)$ & $26(18-45)$ & $24(17-37)^{d}$ \\
\hline
\end{tabular}


Table 2: Serological outcome data according to ethnicity

\begin{tabular}{|c|c|c|c|}
\hline & $\begin{array}{c}\text { Caucasians } \\
(n=607)\end{array}$ & $\begin{array}{c}\text { African } \\
\text { immigrants } \\
(n=168) \\
\end{array}$ & $\begin{array}{c}\text { South African } \\
\text { residents } \\
(n=242)\end{array}$ \\
\hline HBsAg, n (\%) & $27(4.4)$ & $15(8.9)$ & $1(0.4)$ \\
\hline Anti-HBc, n (\%) & $251(41.4)$ & $97(57.7)$ & $68(28.1)$ \\
\hline - also anti-HBs positive, $n(\%)^{a}$ & $173 / 230(75.2)$ & $47 / 83(56.6)$ & $37 / 59(62.7)$ \\
\hline Anti-HCV, n (\%) & $66(10.9)$ & $8(4.8)$ & $2(0.8)$ \\
\hline
\end{tabular}




\section{Table 3:}

Predictors of an occult HBV infection in anti-HBc positive individuals

\begin{tabular}{lcccc}
\hline & $\begin{array}{c}\text { Occult HBV } \\
\text { Yes }\end{array}$ & $\begin{array}{c}\text { Occult HBV } \\
\text { No }\end{array}$ & $\begin{array}{c}\text { Univariate } \\
\text { P value }\end{array}$ & $\begin{array}{c}\text { Multivariate } \\
\text { P value }\end{array}$ \\
\hline CD4 (mean, cells/mm ${ }^{3}$ ) & 214 & 363 & $\mathbf{0 . 0 6}$ & 0.06 \\
Presence of anti-HCV (\%) & 7.1 & 11.8 & 0.94 & - \\
Presence of anti-HBs (\%) & 63.6 & 67.9 & 0.77 & - \\
10log HIV-RNA (mean) & 5.0 & 4.5 & 0.25 & - \\
Ethnic origin (\%) & & & $\mathbf{0 . 0 2}$ & 0.18 \\
- Caucasians & 46.2 & 59.1 & & \\
- African immigrants & 7.7 & 24.4 & & - \\
- South Africans & 46.2 & 16.5 & & \\
Male gender (\%) & 64.3 & 72.4 & 0.51 & \\
HIV transmission route (\%) & & & 0.70 & \\
- Heterosexual & 57.1 & 48.3 & & \\
- Homosexual & 35.7 & 46.1 & & \\
- IV drug use & 7.1 & 3.3 & & \\
- Blood transfusions & 0 & 2.2 & & \\
\hline CD4: number of CD4+ T-cells, \%: percentage of patients, IV drug use: intravenous drug use &
\end{tabular}

